\title{
Budaya Disiplin dan Ta'zir Santri di Pondok Pesantren
}

\author{
Abdurahman \\ Sekolah Tinggi Agama Islam Negeri (STAIN) Sorong, Papua Barat \\ abdrahman_ogi_kuttu@yahoo.co.id
}

\begin{abstract}
The discipline of student needs to be sought to support the success of teaching and learning process in Boarding School. Therefore, Boarding school needs to seek situation and condition that can help student in developing self-discipline. The purpose of this study is to determine the culture of students discipline at boarding school. This article shows that the discipline of student is grown from several factors including: 1) innate factors; 2) awareness factor; 3) interest factors; and 4) the influence factor of mindset. Discipline deals with the process of changing the behavior. As for some things that can change the behavior of the students are: the rules of boarding school and the application of punishment for behavior change. The purpose of discipline coaching is two things: the near and the long term. The near-term goal of disciplinary coaching is to get children trained and controlled, by teaching them appropriate forms of behavior. While the long-term goal is the development of self-control and self-direction, where children can direct themselves, without outside influence. Self-control means mastering self-behavior with guided clear norms, standards, and rules that are self-owned.
\end{abstract}

Keywords: Students' Discipline, Punishment, and Success. 


\section{Pendahuluan}

Bukan hanya transfer of knowledge, pendidikan juga merupakan proses pembentukan watak dan sikap. Sebagai sebuah proses, pendidikan memerlukan kedisiplinan, sementara kedisiplinan itu sendiri merupakan suatu kondisi yang tercipta dan terbentuk melalui proses dari serangkaian perilaku yang menunjukkan nilai-nilai ketaatan, kepatuhan, kesetiaan, keteraturan, dan atau ketertiban. ${ }^{1}$ Oleh karena itu, kedisiplinan sesungguhnya merupakan unsur yang paling penting dalam pendidikan karena memiliki potensi sebagai alat mengubah dan menyesuaikan. ${ }^{2}$ Proses pendidikan dapat ditemukan pada lembaga-lembaga penyelenggara pendidikan, baik lembaga formal seperti sekolah atau madrasah dalam berbagai tingkatan maupun yang non-formal seperti pesantren dan informal seperti lembaga-lembaga kursus dan kepelatihan. Pesantren adalah lembaga pendidikan non-formal ${ }^{3}$ di Indonesia yang salah satu ciri utamanya ialah pemaduan antara proses pengajaran dan pendidikan dalam satu lingkungan terbatas. Istilah pesantren berasal dari kata dasar santri yang mendapatkan imbuhan pe- dan -an, menjadi pesantrian dan kemudian lazim disebut pesantren, artinya tempat (para) santri. ${ }^{4}$

Jika dibandingkan dengan sekolah dan madrasah, sebagai lembaga pendidikan, pesantren memiliki perbedaan yang khas, selain aspek kurikulum dan manajemennya, yakni aspek budaya interaksi para sivitasnya. Hubungan-hubungan itu dalam lembaga pendidikan formal senantiasa dibatasi oleh status formal, sedangkan dalam pesantren, hubungannya

1 Prijodarminto, Soegeng, Disiplin Kiat Menuju Sukses (Jakarta: Pradnya Paramita, 1987), 23.

2 Siti Meichati, Pendidikan Sistematis (Yogyakarta: FIP IKIP Yogyakarta), 7.

3 Masih memungkinkan untuk diperdebatkan apakah pesantren adalah lembaga pendidikan non-formal ataukah formal. Perkembangan pendekatan, metoda, fasilitas dan materi pendidikan di pesantren yang telah berubah seiring perkembangan zaman dan ilmu pengetahuan membuat pesantren mulai dapat dikategorikan sebagai lembaga formal dalam berbagai aspek.

4 Dhofier Zamakhsyari, Tradisi Pesantren: Studi Tentang Pandangan Hidup Kiai (Yogyakarta: LP3ES Lembaga Penelitian, Pendidikan, dan Penerangan Ekonomi dan Sosial, 1982), 18. 
bersifat interpersonal. Hubungan formal berkaitan dengan status formal dan itu berarti status yang melekat pada individu selama yang bersangkutan menyandang formalitasnya, seperti guru, murid, pegawai, pesuruh, dan sebagainya. Sedangkan dalam pesantren, hubungan interpersonal melekat pada tiap individu dan tidak berkaitan dengan status formalnya dalam lingkungan pesantren itu.

Santri memiliki hubungan yang khas dan melekat tanpa dibatasi waktu terhadap kiainya, dan begitu pula kiai terhadap santri. Tanpa bermaksud memandang sebelah mata pada sistem pendidikan secara umum, atau tata-pergaulan dalam dunia pendidikan formal khususnya, dunia pergaulan interpersonal dalam pesantren lebih kekal. Dalam pendidikan formal, seorang murid dapat mencapai tingkat pendidikan paling tinggi dan oleh dengan demikian akan melebihi ketinggian tingkat status dan gelar akademik (mantan) gurunya; dalam kondisi seperti itu, biasanya yang muncul ialah bahwa hubungan antara (mantan) guru-murid ini berubah. Guru yang menyadari perubahan status akademik (mantan) muridnya akan menunjukkan sikap merendah dan sikap sebaliknya terjadi pada (mantan) muridnya. Pertemuan terjadi di tengah-tengah, meskipun tidak secara tepat, yakni kini (mantan) murid dan guru itu sejajar, sejajar dalam hak berpendapat, bahkan dalam cara menyampaikan pendapatnya itu, atau lebih tepatnya dalam sikap pergaulan antara mereka. Gejala ini tidak ditemukan pada dunia pesantren. Sekali seseorang menjadi santri dan yang lain adalah kiai, maka selamanya mereka akan berhubungan dengan cara itu dan dalam kerangka sistem pergaulan yang sama. ${ }^{5}$ Perbedaan kultur pendidikan di dua lembaga pendidikan inilah yang penulis jadikan sebagai gagasan awal melakukan penelitian ini. Meskipun kultur pendidikannya berbeda, namun dalam satu hal, memandang penting kedisiplinan, madrasah dan pesantren memiliki kesamaan.

5 Banyak pihak menyoroti gejala ini dan memandangnya sebagai feodalisme pesantren atau terminologi lain yang bersifat minor. Penelitian ini tidak akan mengikuti arus penilaian preskriptif-subjektif seperti itu, karena lebih difokuskan pada pemikiran mengenai bagaimana memotret tata-pergaulan dan budaya pesantren secara deskriptifobjektif. 
Artikel ini membahas secara jelas bagaimana ta'zir dan disiplin di pesantren mempunyai korelasi penting dalam menopang keberhasilan santri dalam menimba ilmu dan wawasan keislaman. Ta'zir, disiplin, dan santri serta keberhasilan dalam menuntut ilmu dan wawasan menjadi inti tulisan ini.

\section{Konsep Ta'zir}

Dalam kamus fikih, kata ta 'zir merupakan bentuk masdar dari kata az-zara yang berarti menolak, sedangkan menurut istilah hukum syara' berarti pencegahan dan pengajaran terhadap tindak pidana yang tidak mempunyai hukum had, kafarat, dan qishas. ${ }^{6}$ Ta'zir adalah suatu perbuatan dimana seseorang secara sadar dan secara sengaja menjatuhkan nestapa pada orang lain dengan tujuan untuk memperbaiki atau melindungi dirinya dari kelemahan jasmani dan rohani, sehingga terhindar dari segala macam pelanggaran. ${ }^{7}$ Dalam al-Qur'an, ta'zir biasanya disebutkan dalam berbagai bentuk uslub, di antaranya ada yang mempergunakan lafaz 'iqab (عقاب ) seperti dalam surat al-Baqarah ([2]: 61 dan 65), dan Ali Imran ([3]: 11); 'adzab (عذاب) seperti dalam surat at-Taubah ([9]: 74), dan Ali Imran ([3]: 21); Rijz ( رجز ( رجز ) seperti dalam Surat al-A'raf ([7]: 134 dan 165); ataupun berbentuk pernyataan (statement). Ta'zir juga berarti hukuman yang berupa memberi pelajaran. Disebut $t a^{\prime} z i r$, karena hukuman tersebut sebenarnya menghalangi terhukum agar tidak kembali kepada jarimah atau dengan kata lain membuatnya jera. Sementara para fuqaha mengartikan ta'zir dengan hukuman yang tidak ditentukan oleh al-Qur'an dan Hadis yang berkaitan dengan kejahatan yang melanggar hak Allah dan hak hamba yang berfungsi untuk memberi pelajaran kepada terhukum dan mencegahnya agar tidak mengulangi kejahatan serupa. ${ }^{8}$ Jadi, $t a^{\prime} z i r$ adalah hukuman yang tidak ditentukan

6 Muhammad Abdul Mujib, et.al., Kamus Istilah Fiqih (Jakarta: Pustaka Firdaus, 1994), 384.

7 Taher Mursal, et.l. Kamus Ilmu Jiwa dan Pendidikan (Bandung: Al-Maarif, 1997), 56.

8 Zanikhan, "Pengertian dan Unsur Jarimah Takzir," http://zanikhan.multiply.com/ 
oleh Allah karena pelanggaran yang dilakukan tidak terdapat had atau kafarah, namun ia seperti hudud dalam hal memberi pelajaran untuk orang lain demi kemaslahatan umat. ${ }^{9}$

Sementara ta'zir oleh masyarakat Indonesia dipahami sebagai hukuman. Hukuman yang dimaksud merupakan hukuman yang bersifat mendidik, karena itu hukuman tersebut harus mengandung unsur-unsur pendidikan baik diputuskan oleh hakim maupun yang dilakukan orang tua atau para pendidik terhadap anaknya. Dalam hal ini tentu berbeda antara hukuman dari Allah kepada hambanya dan hukuman khusus yang dikeluarkan negara kepada rakyatnya dengan hukuman yang diterapkan orang tua dalam keluarga dan para pendidik dalam dunia pendidikan. Meskipun baik hudud atau ta'zir, keduanya sama-sama bertujuan untuk memberi pelajaran baik bagi si pelaku ataupun orang lain, semua itu merupakan cara yang tegas dan cepat untuk memperbaikinya. ${ }^{10}$

Sedangkan ta'zir dalam istilah psikologi adalah cara yang digunakan pada waktu keadaan yang merugikan atau pengalaman yang tidak menyenangkan yang dilakukan oleh seseorang yang dengan sengaja menjatuhkan orang lain. Secara umum disepakati bahwa hukuman adalah ketidaknyamanan (suasana tidak menyenangkan) dan perlakuan yang buruk atau jelek. ${ }^{11}$ Elizabeth B. Hurlock mendefinisikan hukuman sebagai berikut: "Punishment means to impose a penalty on a person for a fault offense or violation or retaliation". Hukuman ialah menjatuhkan suatu siksa pada seseorang karena suatu pelanggaran atau kesalahan sebagai ganjaran atau balasannya. Sedangkan Athiyah al-Abrasyi berpendapat bahwa:

journal/item/694.

9 Ruswan Thoyib, et.al., Pemikiran Pendidikan Islam Kajian Tokoh Klasik dan Kontemporer (Yogyakarta: Pustaka Pelajar, 1999), 72.

${ }^{10}$ Abdullah Nasih Ulwan, Pendidikan Anak dalam Islam, Jilid II (Jakarta: Pustaka Amani, 1999), 311.

${ }^{11}$ Abdurrahman Mas'ud, "Reward and Punishment dalam Pendidikan Islam," Jurnal Media, Edisi 28, Th. IV (November 1999), 23; lihat juga, Muhammad Athiyah al-Abrasyi, Tarbiyah al-Islamiyyah wa Falsafatuha (Mesir: Isa al-Bani alHalabi, 1975), 150 


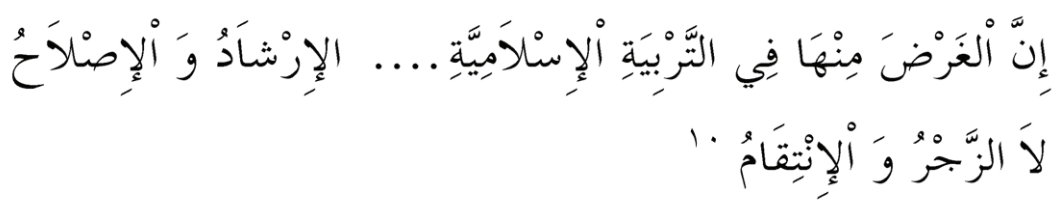

Tujuan hukuman dalam pendidikan Islam adalah sebagai tuntunan dan perbaikan, bukan sebagai hardikan dan hukuman fisik.

Dari beberapa uraian tentang pengertian $t a^{\prime} z i r$ di atas dapat diambil kesimpulan bahwa ta'zir merupakan hukuman yang bersifat memberikan pengajaran terhadap perbuatan seseorang yang tidak dihukum dengan hukuman hudud. Pelaksanaan hukuman ta'zir ini diserahkan kepada orang yang mempunyai kekuasaan yang akan menjatuhkan hukuman. Dalam hal ini, hakim atau orang yang mempunyai kekuasaan memiliki kebebasan untuk menetapkan hukuman ta'zir kepada pelanggar aturan yang hukumannya tidak disebutkan dalam al-Qur'an. Pemberian hak ini adalah untuk mengatur kehidupan masyarakat atau kelompok secara tertib dan untuk mengantisipasi berbagai hal yang tidak diinginkan.

Berkaitan dengan konsep hukuman maupun pahala dengan jelas Allah Swt. telah menggariskan dalam al-Qur'an, yang di antaranya:

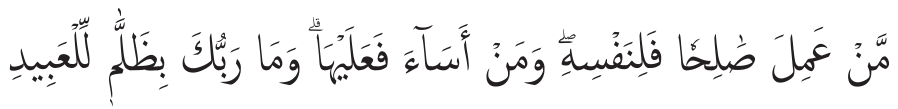

Barang siapa yang mengerjakan amal yang saleh maka (pahalanya) untuk dirinya sendiri dan barang siapa yang berbuat jahat maka (dosanya) atas dirinya sendiri; dan sekali-kali tidaklah Tuhanmu menganiaya hamba-hamba (Nya). (Q.S. Fushshilat [41]: 46) ${ }^{12}$

Dari ayat di atas Allah mengajarkan kepada manusia bahwa setiap manusia akan menerima konsekuensi dari perbuatannya. Baik atau buruk yang dia terima tentunya berbanding searah dengan apa yang telah dilakukannya. Dalam QS. Ali Imron ([3]: 56-57) Allah menjelaskan:

12 Mujamma' Khadim al-Haramain asy-Syarifain al-Malik Fahd li Thiba'at al-Mush-haf asy-Syarif, al Qur'an dan Terjemahnya, 780. 


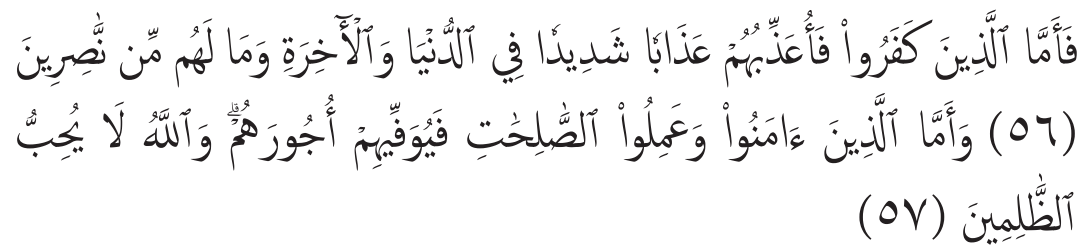

Adapun orang-orang yang kafir, maka akan Ku-siksa mereka dengan siksa yang sangat keras di dunia dan di akhirat, dan mereka tidak memperoleh penolong \{56\}. Adapun orang-orang yang beriman dan mengerjakan amal-amal saleh, maka Allah akan memberikan kepada mereka dengan sempurna pahala amalanamalan mereka; dan Allah tidak menyukai orang-orang yang lalim $\{57\} .^{13}$

Berdasarkan ayat di atas dapat dipahami, bahwa setiap perbuatan pasti ada konsekuensinya, baik itu positif maupun negatif, dan baik atau buruk perbuatan seseorang akan mengenai dirinya sendiri. Oleh karena itu, hukuman pada dasarnya merupakan akibat dari perbuatan manusia sendiri, dan Allah sama sekali tidak berbuat aniaya terhadap manusia. Sedangkan dalam Hadis diterangkan sebagai berikut:

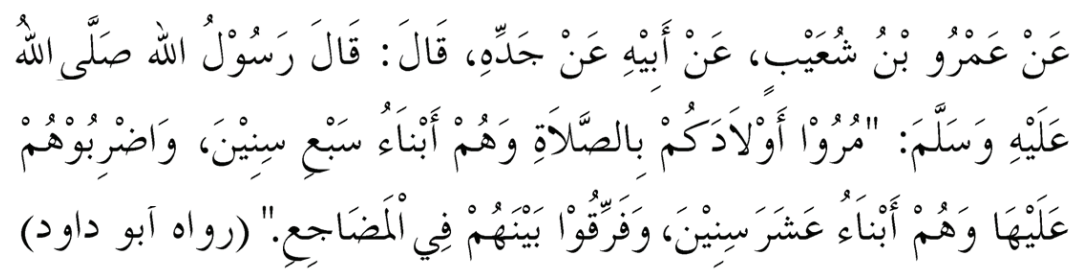

Dari Amr bin Syu'aib dari ayahnya, dari kakeknya bahwa: Rasulullah Saw bersabda: "Suruhlah anak-anak kalian mengerjakan shalat sejak mereka berusia tujuh tahun. Pukullah mereka jika melalaikannya ketika mereka berusia sepuluh tahun dan pisahkan tempat tidur mereka. (HR. Abu Daud) ${ }^{14}$

\footnotetext{
${ }^{13}$ Ibid., 84-85.

${ }^{14}$ Muhammad Muhyiddin Abdul Hamid, Sunan Abu Daud, Juz I (Indonesia: Maktabah Dahlan, tt), 133.
} 
Berdasarkan ayat dan Hadis di atas, dijelaskan bahwa barang siapa mengerjakan dosa atau kesalahan, maka akan mendapatkan hukuman sesuai dengan tingkat kesalahan yang dilakukannya. Secara rasional, ibadah seperti shalat, puasa, dan ibadah lainnya sangat berperan mendidik pribadi manusia yang kesadaran dan pikirannya senantiasa berfungsi dalam pekerjaannya. ${ }^{15}$ Dari Hadis di atas dapat dipahami bahwa anak harus diperintahkan mengerjakan shalat ketika berusia tujuh tahun, dan diberi hukuman pukul apabila anak menolak mengerjakan shalat jika sudah berusia sepuluh tahun. Tujuan diberikannya hukuman ini supaya anak menyadari kesalahannya.

Menurut Emile Durkheim, dalam dunia pendidikan ada teori pencegahan. Dalam teori ini, hukuman merupakan suatu cara untuk mencegah akan adanya berbagai pelanggaran terhadap peraturan. Pendidikan menghukum si anak selain agar anak tidak mengulangi kesalahannya untuk mencegah agar anak lain tidak menirunya. ${ }^{16}$ Sedangkan Asma Hasan Fahmi mengungkapkan tujuan hukuman dalam pendidikan Islam:

Tujuan hukuman mengandung arti positif, karena ia ditujukan untuk memperoleh perbaikan dan pengarahan, bukan sematamata untuk membalas dendam. Oleh karena itu, orang Islam sangat ingin mengetahui tabiat dan perangai anak-anak sebelum menghukum mereka, sebagaimana mereka ingin sekali mendorong anak-anak ikut aktif dalam memperbaiki kesalahan mereka sendiri, dan untuk ini mereka melupakan kesalahan anak-anak dan tidak membeberkan rahasia mereka. ${ }^{17}$

Berdasarkan tujuan hukuman di atas, maka dapat diambil pengertian bahwa tujuan hukuman dalam pendidikan Islam adalah untuk per-

\footnotetext{
${ }^{15}$ Muhammad Ali Quthb, Auladuna fi Dlau'i at-Tarbiyah al-Islamiyah: Sang Anak dalam Naungan Pendidikan Islam (Kairo: Maktabah Qur'an, 1993), 89.

${ }^{16}$ Emile Durkheim, Pendidikan Moral: Suatu Studi Teori dan Aplikasi Sosiologi Pendidikan (Jakarta: Erlangga, 1990), 116.

${ }^{17}$ Asma Hasan Fahmi, Sejarah Filsafat Pendidikan Islam (Jakarta: Bulan Bintang, 1979), 140.
} 
baikan kesalahan yang dilakukan anak-anak. Sedangkan tujuan pokok hukuman dalam syari'at Islam adalah untuk pencegahan, pengajaran, dan pendidikan. Adapun tujuan hukuman dalam pendidikan adalah untuk memperbaiki tabiat dan tingkah laku anak ke arah kebaikan dan anak akan menyesali serta menyadari perbuatan salah yang telah dilakukannya. Selain itu, hukuman dianggap sebagai alat pendidikan yang istimewa kedudukannya, karena hukuman membuat anak didik menderita, dan dengan penderitaan tersebut anak akan merasa jera, sehingga anak akan memilih mematuhi peraturan dari pada melanggarnya.

Makna dari kata ( وَاضْرُبُوا ) dalam Hadis tersebut berarti memberikan hukuman yang berupa pukulan secara fisik, karena anak meninggalkan shalat. Di samping itu, pukulan yang diberikan harus mengenai badannya dan tidak mengenai wajahnya. Oleh karena itu, pukulan tersebut harus diberikan kepada anak ketika sudah berumur sepuluh tahun, karena pada usia sepuluh tahun ke atas ini seorang anak sudah dianggap mempunyai tanggung jawab (baligh). ${ }^{18}$ Hukuman dengan memukul adalah hal yang diterapkan oleh Islam sebagaimana Hadis Nabi di atas. Hal ini dilakukan pada tahap terakhir setelah nasihat dan cara lain tidak berhasil. Tata cara yang tertib ini menunjukkan bahwa pendidik tidak boleh menggunakan cara yang lebih keras jika yang lebih ringan sudah bermanfaat, sebab pukulan adalah hukuman yang paling berat dan dia tidak boleh menggunakannya, kecuali jika dengan jalan lain masih tidak bisa, dan perlu diketahui pula bahwa Rasulullah Saw. sama sekali tidak pernah memukul seorangpun dari istri-istrinya. Praktik ta'zir atau hukuman sebenarnya sudah lama dikenal, dan hukuman akan terus mengalami perubahan karena adanya pergantian zaman dan peralihan dari satu generasi ke generasi lain, ditambah dengan kegiatan dan kebutuhan manusia yang semakin kompleks. Dari sisi istilah yang digunakan sama, hanya saja penerapannya yang berbeda. Namun demikian, Islam telah memberikan dan menunjukkan batasan dan pengertian yang jelas antara ganjaran dan hukuman tersebut. Adapun tujuan hukuman dalam pendidikan adalah:

\footnotetext{
${ }^{18}$ Abu Thayyib Muhammad Syamsul Haq, Aunul Ma'bud: Syarah Sunan Abu Daud, Juz II (Beirut: Daar al-Fikr, tt), 161.
} 
1. Untuk memperbaiki individu yang bersangkutan agar menyadari kekeliruannya, dan tidak akan mengulanginya lagi.

2. Melindungi pelakunya agar dia tidak melanjutkan pola tingkah laku yang menyimpang, buruk, dan tercela.

3. Sekaligus juga melindungi masyarakat luar dari perbuatan salah (nakal, jahat, asusila, kriminal, abnormal, dan lain-lain) yang dilakukan oleh anak atau orang dewasa. ${ }^{19}$

\section{Konsep Kedisiplinan}

Kedisiplinan berasal dari bahasa Inggris discipline, sedangkan dalam bahasa Arab disebut nidham ( النظام ). Kata kedisiplinan berasal dari kata dasar disiplin yang mendapat prefiks ke- dan -an yang mempunyai arti ketaatan (kepatuhan) kepada peraturan (tata tertib dan sebagainya). ${ }^{20}$ Sedangkan dalam bahasa Inggris, discipline diartikan sebagai training or control, often using a system of punishment, aimed at producing obedient to rules $^{21}$ (pelatihan atau pengaturan, sering menggunakan seperangkat hukuman, yang dimaksudkan untuk menghasilkan ketaatan terhadap peraturan). Secara istilah, Keith Davis mengemukakan bahwa disiplin merupakan pengawasan terhadap diri pribadi untuk melaksanakan segala sesuatu yang telah disetujui atau diterima sebagai tanggung jawab. ${ }^{22}$

Sedangkan dalam buku Ways to Help Your Children Grow dijelaskan: Discipline is a form of life training that, once experienced and when practiced, develops an individual's ability to control themselves ${ }^{23}$ (Disiplin adalah

\footnotetext{
${ }^{19}$ Abu Thayyib Muhammad Syamsul Haq, Aunul Ma'bud: Syarah Sunan Abu Daud, Juz II (Beirut: Daar al-Fikr, tt), 161.

${ }^{20}$ Kartini Kartono, Pengantar Mendidik Ilmu Teoritis: Apakah Pendidikan Masih Diperlukan (Bandung: Mandar Maju, 1992), 261.

${ }^{21}$ Lukman Ali, et.al., Kamus Besar Bahasa Indonesia (Jakarta: Balai Pustaka, 1997), 237.

${ }^{22}$ RA. Santoso Sastropoetra, Partisipasi, Komunikasi, Persuasi, dan Disiplin dalam Pembangunan Nasional (Bandung: Penerbit Alumni, 1988), 286.

${ }^{23}$ Sheila Ellison \& Barbara Ann Barnett, 35 Ways to Help Your Children Grow (Illi-
} 
suatu bentuk pelatihan hidup yang, merupakan satu pengalaman dan ketika dipraktikkan, akan menghasilkan kemampuan individu untuk mengendalikan diri mereka sendiri). Sementara Mahmud Yunus mengatakan:

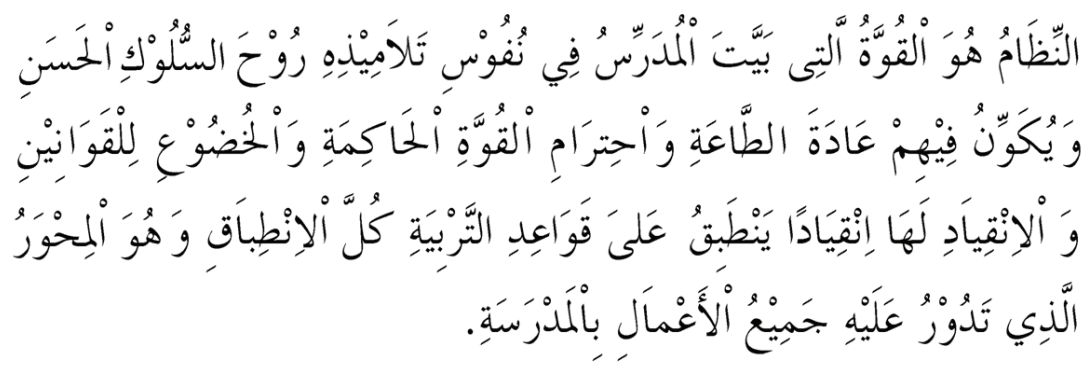

Disiplin adalah kekuatan yang diutamakan oleh para pendidik untuk menanamkan dalam jiwa tentang tingkah laku yang baik dalam pribadi murid dan membentuk kebiasaan taat dalam diri mereka, kehormatan yang kokoh, dan tunduk dengan sebenarbenarnya pada aturan-aturan yang sesuai dengan prinsip pendidikan yang sesungguhnya, dan itu merupakan inti yang dijalankan pada setiap aktivitas sekolah.

Sedangkan disiplin menurut Soegeng Prijodarminto adalah suatu kondisi yang tercipta dan terbentuk melalui proses dari serangkaian perilaku yang menunjukkan nilai-nilai ketaatan, kepatuhan, kesetiaan, keteraturan, dan atau ketertiban. ${ }^{24}$ Gerakan Disiplin Nasional (GDN) menegaskan bahwa disiplin merupakan ketaatan terhadap peraturan dan norma kehidupan bermasyarakat, berbangsa dan bernegara yang berlaku yang dilaksanakan secara sadar dan ikhlas lahir batin, sehingga timbul rasa malu apabila terkena sanksi dan rasa takut kepada Tuhan Yang Maha Esa. ${ }^{25}$ Sementara C. Ralph Taylor mengatakan, "Discipline is training that strengthens; correction, punishment, control or order maintained; a

nois: Sourcebooks Inc, 1996), 195.

${ }^{24}$ Soegeng Prijodarminto, Disiplin Kiat Menuju Sukses (Jakarta: Pradnya Paramita, 1994), 23.

${ }^{25}$ Sehedi Hendro, Gerakan Disiplin Nasional (GDN) Menyongsong Era Keterbukaan Tahun 2020 (Jakarta: CV. Navindo Pustaka Mandiri, 1996), 130. 
system of rules for conduct." Disiplin adalah latihan untuk menguatkan, membenarkan, memberi hukuman, mengontrol atau perintah yang diperintahkan, suatu sistem aturan kepemimpinan. Dari definisi-definisi tersebut dapat disimpulkan bahwa disiplin adalah suatu kondisi yang tercipta melalui proses latihan yang dikembangkan menjadi serangkaian perilaku yang di dalamnya terdapat unsur-unsur ketaatan, kepatuhan, kesetiaan, ketertiban, dan semua itu dilakukan sebagai tanggung jawab yang bertujuan untuk mawas diri.

Sebagai makhluk sosial, manusia tidak bisa hidup sendirian dan akan selalu berinteraksi dengan sesamanya. Dalam interaksi itu manusia terikat oleh suatu peraturan, norma atau tata tertib yang mengatur perilakunya. Maka manusia dituntut wajib mengikuti peraturan atau norma-norma yang mengatur cara hidupnya dimana dia tinggal. Dalam mengikuti peraturan tersebut diperlukan sikap disiplin yang dimiliki oleh setiap manusia. Sebab, tanpa adanya kesadaran bersikap disiplin pada setiap individu, dapat menimbulkan ketidakteraturan dalam hidup. Disiplin merupakan faktor yang sangat penting dalam kehidupan baik di lingkungan keluarga, sekolah, pondok pesantren maupun masyarakat. Di pesantren, disiplin juga sangat diperlukan karena akan mendukung keberhasilan proses belajar mengajar. Hal ini sesuai dengan yang diungkapkan Rudolf Dreikurs, bahwa disiplin merupakan titik pusat dalam pendidikan. Menurutnya dalam proses belajar mengajar tanpa disiplin tidak akan ada kesepakatan antara guru dan murid, dan hasil pelajaran pun berkurang. ${ }^{26}$ Dengan demikian, apabila disiplin diterapkan dengan baik, konsisten, dan konsekuen, tentu akan berdampak positif bagi kehidupan dan perilaku peserta didik. Oleh karena itu, pesantren perlu mengupayakan situasi dan kondisi yang bisa membantu santri dalam mengembangkan disiplin diri. Upaya untuk mengembangkan disiplin diri bisa dilakukan dengan mengundang anak-anak untuk mengaktifkan diri dengan nilai-nilai moral untuk memiliki dan mengembangkan dasardasar disiplin diri. Upaya tersebut menunjukkan perlu adanya posisi dan

\footnotetext{
${ }^{26}$ Rudolf Dreikurs \& Pearl Cassel, Disiplin tanpa Hukuman (Bandung: Remaja Karya, 1986), 6 .
} 
tanggung jawab dari orang tua, karena orang tualah yang berkewajiban meletakkan dasar-dasar disiplin diri kepada anak mereka.

Pesantren sebagai kepanjangan tangan dari orang tua santri sudah seharusnya memberikan pembinaan dengan kedisiplinan. Karena disiplin yang sudah ada pada diri santri akan dapat terwujud dengan baik apabila dibina sejak dini, sejak usia muda, dimulai dari lingkungan keluarga, melalui pendidikan dan tertanam sejak usia muda. Dengan pembinaan yang lama, maka disiplin akan menyatu kuat dalam dirinya dengan bertambahnya usia. ${ }^{27}$ Pembinaan kedisiplinan anak dilakukan mulai dari kecil karena perilaku dan sikap disiplin seseorang terbentuk tidak secara otomatis, namun melalui proses yang panjang dan tidak dibentuk dalam waktu yang singkat. Disiplin dalam Islam sangat dianjurkan untuk selalu diaktualisasikan dalam kehidupan sehari-hari. Anjuran ini secara implisit tertuang dalam al-Qur'an Surat al-'Ashr ([103]: 1-3):

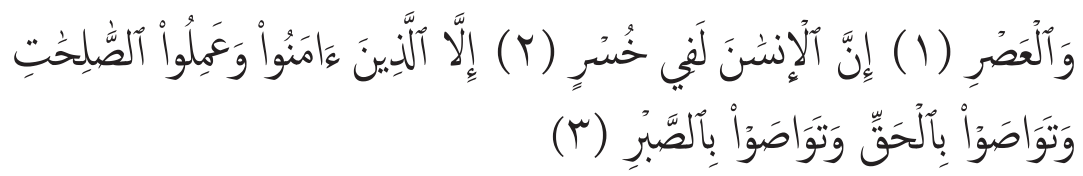

Demi masa. Sesungguhnya manusia itu benar-benar berada dalam kerugian, kecuali orang-orang yang beriman dan mengerjakan amal saleh dan nasihat menasihati supaya menaati kebenaran dan nasihat menasihati supaya menetapi kesabaran..$^{28}$

Dari ayat tersebut dapat diketahui bahwa Allah menyuruh manusia agar dapat memanfaatkan waktu dengan baik, yaitu tidak menyia-nyiakan waktu yang tersedia dengan melakukan perbuatan yang tidak bermanfaat. Ini menunjukkan bahwa Allah menyuruh manusia untuk berlaku disiplin dalam menggunakan waktu yang tersedia. Namun, perintah disiplin tersebut tidak terbatas pada aspek waktu saja, akan tetapi disiplin yang diaktualisasikan dalam segala aspek kehidupan. Kedisiplinan bukan

\footnotetext{
${ }^{27}$ Soegeng Prijodarminto, Disiplin Kiat Menuju Sukses (Jakarta: Abadi, 1994), 17.

28 asy-Syarif, al-Qur'an dan Terjemahnya, 1099.
} 
merupakan sesuatu yang terjadi secara otomatis atau spontan pada diri seseorang, melainkan sikap tersebut terbentuk atas dasar beberapa faktor yang mempengaruhinya. Adapun faktor-faktor tersebut adalah:

1. Faktor pembawaan. Menurut aliran nativisme bahwa nasib anak itu sebagian besar berpusat pada pembawaannya, sedangkan pengaruh dari lingkungannya hanya sedikit. Baik buruknya perkembangan anak, sepenuhnya tergantung pada pembawaannya. ${ }^{29}$ Pendapat tersebut menunjukkan bahwa salah satu faktor yang menyebabkan orang bersikap disiplin adalah pembawaan yang merupakan warisan dari keturunannya.

2. Faktor kesadaran. Kesadaran adalah hati yang telah terbuka atas pikiran yang telah terbuka tentang apa yang telah dikerjakan. ${ }^{30}$ Disiplin akan lebih mudah ditegakkan bilamana timbul dari kesadaran setiap individu, untuk selalu mau bertindak taat, patuh, tertib, teratur, bukan karena ada tekanan atau paksaan dari luar. ${ }^{31}$ Dengan demikian, seseorang akan berperilaku disiplin jika dia memiliki kesadaran atau pikirannya telah terbuka untuk melakukan kedisiplinan.

3. Faktor minat. Minat adalah suatu perangkat manfaat yang terdiri dari kombinasi, perpaduan dan campuran dari perasaan, harapan, prasangka, cemas, takut, dan kecenderungan-kecenderungan lain yang bisa mengarahkan individu kepada suatu pilihan tertentu. ${ }^{32}$ Dalam berdisiplin, minat sangat berpengaruh untuk meningkatkan keinginan yang ada dalam diri seseorang. Jika minat seseorang dalam berdisiplin sangat kuat maka dengan sendirinya dia akan berperilaku disiplin tanpa menunggu dorongan dari luar.

\footnotetext{
${ }^{29}$ Moh, Kasiram, Ilmu Jiwa Perkembangan (Surabaya: Usaha Nasional, 1983$), 27$.

${ }^{30}$ Djoko Widagdho, et.al., Ilmu Budaya Dasar (Jakarta: Bumi Aksara, 1994), 152.

${ }^{31}$ Prijodarminto, Disiplin Kiat Menuju, 15.

${ }^{32}$ Dewa Ketut Sukardi, Bimbingan Karir di Sekolah-Sekolah (Jakarta: CV. Ghalia Indonesia, 1994), 46.
} 
4. Faktor pengaruh pola piker. Tentang pengaruh pola pikir, para ahli ilmu jiwa berpendapat bahwa pikiran itu tentu mendahului perbuatan, maka perbuatan berkehendak itu dapat dilakukan setelah pikirannya. ${ }^{33}$

Setiap manusia mempunyai tujuan tertentu dalam melaksanakan sikap dan perbuatannya. Tujuan disiplin menurut Ellen G. White ialah:

1. Pemerintahan atas diri;

2. Menaklukkan kuasa kemauan;

3. Perbaiki kebiasaan-kebiasaan;

4. Hancurkan benteng syetan;

5. Ajar menghormati orang tua dan ilahi; dan

6. Penurutan atas dasar prinsip, bukan paksaan. ${ }^{34}$

Sementara Emile Durkheim mengatakan bahwa disiplin mempunyai tujuan ganda yaitu mengembangkan suatu keteraturan dalam tindak tanduk manusia dan memberinya suatu sasaran tertentu yang sekaligus membatasi cakrawalanya. ${ }^{35}$ Kalau dilihat dari sisi tujuan, pelaksanaan pembinaan kedisiplinan mempunyai dua tujuan, yaitu tujuan jangka dekat dan tujuan jangka panjang. Tujuan jangka dekat pembinaan kedisiplinan adalah untuk membuat anakanak terlatih dan terkontrol, dengan mengajarkan mereka bentuk-bentuk tingkah laku yang pantas atau yang masih asing bagi mereka. Sedangkan tujuan jangka panjang pembinaan kedisiplinan adalah perkembangan dari pengendalian diri (self control) dan pengarahan diri sendiri (self direction), dimana anak dapat mengarahkan diri sendiri tanpa pengaruh dari luar. Pengendalian diri berarti menguasai tingkah laku diri sendiri dengan berpedoman norma-norma yang jelas, standar-standar, dan aturan-aturan yang sudah menjadi milik diri sendiri. ${ }^{36}$

\footnotetext{
${ }^{33}$ Ahmad Amin, Etika (Jakarta: Bulan Bintang, 1975), 30.

${ }^{34}$ Ellen G. White, Mendidik dan Membimbing Anak (Bandung: Indonesia Publishing House, 1998), 213-214.

${ }^{35}$ Durkheim, Pendidikan Moral, 35.

${ }^{36}$ Charles Schaefer, Bagaimana Mendidik dan Mendisiplinkan Anak (Medan: Monora,
} 
Dengan demikian, tujuan pembinaan secara umum adalah untuk menanamkan kesadaran pada anak supaya bertingkah laku berdasarkan nilai-nilai agama, nilai budaya, aturan-aturan pergaulan, pandangan hidup, dan sikap hidup yang bermakna bagi anak sehingga memiliki kepribadian baik dan disiplin diri. Disiplin yang tumbuh pada anak tidak muncul secara otomatis, namun disiplin ada karena adanya suatu perbuatan yang dapat mendorong ke arah perilaku dan sikap tersebut. Perbuatan yang diarahkan untuk tercapainya kesadaran anak untuk disiplin yang lebih baik memerlukan pendekatan yang baik.

Disiplin yang dipaksakan (disiplin otoriter) yaitu pendisiplinan yang dilakukakan secara paksa. Anak diharuskan mengikuti aturan yang telah ditentukan. Apabila anak tidak melakukan perintah, ia bisa dihukum dengan sanksi hukuman fisik, mengurangi pemberian materi, membatasi pemberian penghargaan atau berupa ancaman langsung dan tidak langsung. Dengan pendekatan disiplin semacam ini, seseorang tidak mempunyai kesempatan untuk mengetahui mengapa disiplin itu harus dilakukan dan apa tujuan penerapan disiplin itu sehingga mereka melakukan sesuatu tidak berdasarkan kesadaran sendiri, namun karena takut akan adanya ancaman dan hukuman.

Penerapan disiplin ini dengan cara membiarkan anak mencari sendiri batasannya. Dalam disiplin ini seseorang dapat bertindak menurut keinginannya, dibebaskan untuk mengambil keputusan sendiri, dan bertindak sesuai dengan keputusan yang diambilnya itu. Seseorang yang berbuat sesuatu dan ternyata membawa akibat melanggar norma atau aturan yang berlaku, tidak diberi sanksi atau hukuman atas perbuatannya itu. Namun, dengan pendekatan disiplin semacam ini seseorang dapat berbuat semuanya tanpa kontrol dan kendali. ${ }^{37}$

Pendekatan disiplin demokratis dilakukan dengan memberi penjelasan, diskusi dan penalaran untuk membantu anak memahami mengapa diharapkan mematuhi dan menaati peraturan yang ada. Teknik

1979), 9.

${ }^{37}$ Bambang Sujiono, et.al., Mencerdaskan Perilaku Anak Usia Dini (Jakarta: PT. Elex Media Komputindo, 2005), 30. 
ini menekankan aspek edukatif bukan aspek hukuman. Sanksi atau hukuman dapat diberikan kepada yang menolak atau melanggar tata tertib. Hukuman dimaksud sebagai upaya menyadarkan, mengoreksi, dan mendidik. ${ }^{38}$ Teknik ini ditandai dengan adanya pengakuan terhadap anak. Anak diberi kesempatan untuk tidak selalu tergantung kepada orang tua atau orang lain. Anak diberi kesempatan mengembangkan kontrol internalnya sehingga sedikit demi sedikit berlatih untuk bertanggung jawab kepada diri sendiri. Beberapa pendekatan disiplin di atas apabila diterapkan pada anak atau santri akan menghasilkan sifat dan tingkah laku anak yang berbeda. Disiplin otoriter akan menjadikan anak patuh ketika ada pemimpin, dan anak akan menjadi kurang kreatif dan perhatian berkurang apabila pemimpinnya tidak ada. Sebaliknya, pembinaan disiplin dengan pendekatan demokratis akan menjadikan anak patuh walaupun tidak ada pemimpin, dan anak yang kreatif karena berani bertanya akan mempunyai tanggung jawab walaupun tidak ada pemimpinnya.

\section{Pentingnya Kedisiplinan Santri dalam Pesantren}

Pesantren yang merupakan "bapak" dari pendidikan Islam di Indonesia didirikan karena adanya tuntutan dan kebutuhan jaman. Hal ini bisa dilihat dari perjalanan sejarah, bila dirunut kembali sesungguhnya pesantren dilahirkan atas kesadaran kewajiban dakwah Islamiyah, yakni menyebarkan dan mengembangkan ajaran Islam sekaligus mencetak kader-kader ulama atau da'i. ${ }^{39}$ Secara historis, pesantren di masa awal berdirinya, biasanya berupa komunitas tertentu yang terdiri dari seorang, atau beberapa guru, ustaz atau kiai yang berperan sebagai pengajar dan sekelompok murid atau santri yang diajar. ${ }^{40}$ Pada perkembangan beri-

\footnotetext{
${ }^{38}$ Benyamin Spock, Raising Children in a Difficult Time, terj. Wunan Jaya K. Liotohe (Jakarta: Gunung Jati, 1982), 9.

${ }^{39}$ Marwan Saridjo, Sejarah Pondok Pesantren di Indonesia (Jakarta: Dharma Bhakti, 1982), 7.

${ }^{40}$ Ahmad Ismail Outhman, Dinamika Pesantren dan Madrasah: Dari Mengaji ke Mengkaji (Semarang: Fakultas Tarbiyah IAIN Walisongo dengan Pustaka Pelajar Yogya-
} 
kutnya, para santri kemudian merasakan kebutuhan untuk berdekatan selalu dengan kiainya, supaya mereka dapat mempelajari dan mengamati lebih banyak lagi pelajaran-pelajaran agama. Mereka kemudian membentuk kelompok masyarakat sendiri yang ditujukan untuk selalu dekat dengan kiainya atau kiai itu sendiri yang menyediakan tempat, di rumahnya, atau di luar rumahnya, untuk menampung mereka supaya setiap saat dapat memberikan pelajaran agama. ${ }^{41}$

Sebagai institusi pendidikan Islam yang dinilai paling tua, pesantren memiliki akar trasmisi sejarah yang jelas. Orang yang pertama kali mendirikannya dapat dilacak meskipun ada perbedaan pemahaman. Di kalangan ahli sejarah terdapat perselisihan pendapat dalam menyebutkan pendiri pesantren pertama kali. Sebagian mereka menyebutkan Syaikh Maulana Malik Ibrahim, yang dikenal dengan Syaikh Maghribi dari Gujarat India, sebagai pendiri/pencipta pondok pesantren yang pertama di Jawa. Ada pula ulama yang menganggap Sunan Gunung Jati (Syaikh Syarif Hidayatullah) di Cirebon sebagai pendiri pesantren pertama, sewaktu mengasingkan diri bersama pengikutnya dalam khalwat, beribadah secara istiqamah untuk ber-taqarrub kepada Allah Swt. ${ }^{42}$

Pondok pesantren umumnya mempunyai aturan-aturan yang harus ditaati oleh para santri sehingga tujuan pendidikan di pesantren dapat terlaksana. Sikap disiplin santri merupakan salah satu tujuan pendidikan di pesantren. Dengan pembiasaan bersikap disiplin, santri akan terlatih dan terkontrol sehingga dapat mengembangkan sikap pengendalian diri (self control) dan pengarahan diri (self direction), santri dapat menentukan sikap secara mandiri tanpa adanya pengaruh dari luar yang cukup berarti. Santri juga akan lebih mudah menyerap pelajaran-pelajaran yang diajarkan di pesantren. Metode khas yang diterapkan di pesantren yaitu hafalan, sorogan, dan bandongan, tidak akan terlaksana dengan baik jika santri tidak mempunyai sikap disiplin. Santri akan mengalami

\footnotetext{
karta, 2002), 73.

${ }^{41}$ Ibid., 74.

${ }^{42}$ Mujamil Qomar, Pesantren: Dari Transformasi Metodologi Menuju Demokratisasi Institusi (Jakarta: Penerbit Erlangga, 1996), 8.
} 
kesulitan menghafal pelajaran, seperti bait dan syair jika tidak disiplin dalam hal waktu. Tentunya santri akan kesulitan membaca atau menerjemahkan suatu kitab jika tidak bisa menerapkan sikap disiplin dalam menelaah kitab, dan sulit bertambah ilmu jika santri tidak disiplin dalam mengikuti pelajaran dengan sistem bandongan. Demikian juga dalam hal ibadah, kedisiplinan santri diperlukan dalam menaati peraturan-peraturan yang sudah ditetapkan kiai, seperti keharusan berjamaah, shalat tahajud, mengaji al-Qur'an setelah maghrib, anjuran melaksanakan puasa sunnah, dan sebagainya. Jika santri menaati peraturan yang sudah ditetapkan kiai maka santri akan memperoleh kerelaan kiai, yang dalam bahasa pesantren lebih dikenal dengan "barakah" sehingga santri mendapatkan ilmu yang bermanfaat. Hal ini sebagaimana dikemukakan oleh az-Zarnuji:

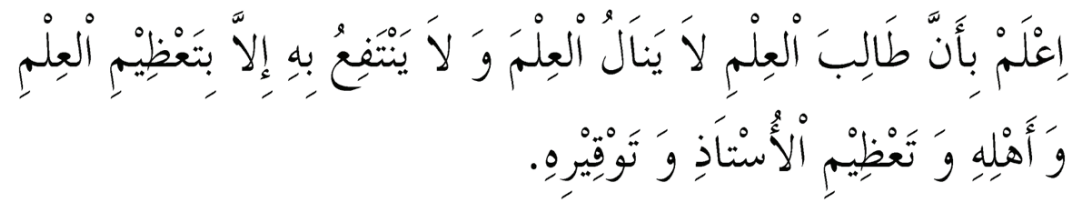

Ketahuilah bahwa sesungguhnya pencari ilmu tidak akan memperoleh ilmu, dan tidak bermanfaat ilmunya kecuali dengan memuliakan ilmu dan ahli ilmu, serta memuliakan guru dan menghormatinya.

Di sini az-Zarnuji mengingatkan kepada mereka yang mencari pengetahuan hendaklah selalu ingat bahwa mereka tidak akan pernah mendapatkan pengetahuan atau pengetahuannya tidak berguna, kecuali kalau ia menaruh hormat kepada pengetahuan tersebut dengan mengamalkan apa yang dia ketahui dan juga menaruh hormat kepada guru yang mengajarkannya. Para santri harus menunjukkan rasa hormat dan takzim serta "kepatuhan mutlak" kepada kiai dan ustaznya, bukan mani-festasi dari penyerahan total kepada orang-orang yang dianggap memiliki otoritas, tetapi karena suatu keyakinan atas kedudukan guru sebagai penyalur kemurahan (barokah) Tuhan yang dilimpahkan kepada muridmuridnya, baik ketika hidup di dunia maupun di akhirat. Lebih 
lanjut, Syaikh Zarnuji mengatakan, menurut ajaran Islam, murid (santri) harus menganggap guru (kiai) seperti ayah kandungnya sendiri. Berdasarkan korpus resmi ala pesantren, seperti dijabarkan dalam kitab Ta’lim. ${ }^{43}$

Kitab al-Muta'allim dan kitab-kitab sejenisnya yang memberikan kontribusi pada sistem nilai yang dianut warga pesantren, kemudian diintrodusir sedemikian rupa dalam praktik-praktik kehidupan santri baik dalam bentuk konvensi-konvensi atau menjadi teknik-teknik disipliner sehingga menjadi tatanan etis yang mengatur hubungan kiai dan santri. Hal ini terus dipelihara, kemudian disosialisasikan dari waktu ke waktu, dari satu generasi ke generasi berikutnya dan akhirnya terinternalisasi pada diri setiap santri. Melalui cara itulah tertib sosial (social order) di lingkungan pesantren bisa ditegakkan. Sedangkan tindakan apapun yang mencoba menyimpang darinya akan dicap indisipliner, mbalelo dan pantas mendapatkan sangsi ( $t a^{\prime} z i r$ ) atau dikenakan denda. Adapun sangsi yang ada bisa dalam bentuk sanksi moral, sosial ataupun berupa sangsi fisik, seperti cukur rambut, membersihkan selokan, dan untuk kasus pelanggaran yang parah bisa dipulangkan kepada orang tua (diboyong). ${ }^{44}$ Sangat dipahami bahwa selain sebagai tempat menimba ilmu, pondok pesantren juga merupakan sarana melatih kedisiplinan bagi para santri. Jika selama di pesantren kedisiplinan santri terlatih dengan baik, tentu besar kemungkinan sikap disiplin itu akan dibawa setelah keluar dari pesantren dan akan sangat bermanfaat dalam kehidupan bermasyarakat.

Disiplin sangat erat kaitannya dengan pendidikan. Pendidikan merupakan usaha yang dilakukan untuk mengubah tingkah laku sedemikian rupa sehingga menjadi tingkah laku yang diinginkan. ${ }^{45}$ Sedangkan disiplin adalah suatu kondisi yang tercipta melalui proses latihan yang dikembangkan menjadi serangkaian perilaku yang di dalamnya terdapat

${ }^{43}$ az-Zarnuji, Ta'lim al-Muta'allim (Semarang: Toha Putra, tt), 16.

${ }^{44}$ Syamsul Hadi Thubany, "Relasi Etis Kiai-Santri," www.pondokpesantren.net/ ponpren/index.php?option=com_content\&task=view\&id=209\&Itemid=28.

${ }^{45}$ Singgih D. Gunarso, Psikologi untuk Membimbing (Jakarta: PT. BPK Gunung Mulia, 2000), 130. 
unsur-unsur ketaatan, kepatuhan, kesetiaan, ketertiban, dan semua itu dilakukan sebagai tanggung jawab yang dilakukan untuk mawas diri. Terlihat jelas bahwa pendidikan dan disiplin mempunyai kesamaan, yaitu sama-sama berhubungan dengan tingkah laku. Pendidikan mengubah tingkah laku dari yang kurang baik menjadi lebih baik. Sedangkan disiplin berkaitan dengan proses mengubah tingkah laku tersebut. Adapun beberapa hal yang perlu menjadi perhatian dalam rangka mengubah tingkah laku para santri adalah:

1. Peraturan. Peraturan adalah pola yang ditetapkan untuk tingkah laku. Tujuannya adalah untuk membekali anak dengan pedoman perilaku yang disetujui dalam situasi tertentu. ${ }^{46}$ Dengan adanya peraturan yang jelas, semua anggota kelompok akan melaksanakannya dengan baik. Di samping harus mentaati peraturan pondok pesantren, santri juga harus memahami dan mentaati pola-pola kebudayaan pondok pesantren yang berlaku. Adanya peraturan ini kemudian menjadi pijakan awal untuk memberikan penghargaan bagi yang memiliki prestasi atau hukuman bagi yang melanggarnya.

2. Hukuman. Hukuman adalah suatu bentuk kerugian atau kesakitan yang ditimpakan kepada orang yang berbuat salah. ${ }^{47}$ Pelaksanaan hukuman dimaksudkan untuk menghalangi santri melakukan perbuatan salah yang pernah dilakukan, untuk mematuhi peraturan, memberi motivasi untuk menghindari perilaku yang tidak diterima di lingkungan pondok pesantren.

Mendidik anak dalam agama Islam tidak terlepas dari adanya hukuman. Pendidikan yang terlalu halus akan berpengaruh kurang baik, karena bisa membuat jiwa tidak stabil. Oleh karena itu, perlu adanya sedikit kekerasan dalam mendidik, di antara bentuk kekerasan itu adalah berwujud hukuman. Mengenai hukuman ini, dalam Surat al-Qashash

${ }^{46}$ Elizabeth B. Hurlock, Perkembangan Anak, terj. Med Meitasari Tjandrasa (Jakarta: Erlangga, 1999), 85.

47 Schaefer, Bagaimana Mendidik, 102. 
([28]: 84), Allah berfirman:

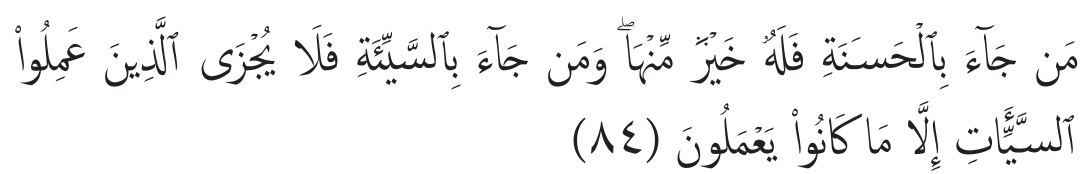

Dan barang siapa yang datang dengan (membawa) kejahatan, maka tidaklah diberi pembalasan kepada orang-orang yang telah mengerjakan kejahatan itu, melainkan (seimbang) dengan apa yang dahulu mereka kerjakan. ${ }^{48}$

Meskipun hukuman atau punishment dalam pendidikan biasanya diberikan kepada siswa atau santri sebagai sanksi atas pelanggaran yang telah diperbuatnya, namun menurut KH. Bisri Musthofa hukuman tidak boleh dilakukan dengan kekerasan, apalagi sampai melukai. Menurutnya, hukuman sebaiknya dilakukan secara persuasif agar murid timbul kesadaran terhadap kesalahan yang diperbuatnya dan kemudian tidak melakukannya lagi. ${ }^{49}$ Prinsip pemberian hukuman yang mengarah kepada upaya penyadaran diri ini sangat sesuai dengan prinsip-prinsip yang diajarkan oleh Islam. Meskipun kehadiran Nabi adalah sebagai nadhir, pemberi peringatan, tapi kehadiran Nabi sebagai basyir dalam proses pendidikan Islam tampak lebih dominan dan signifikan. Sebagai basyir, pembawa kabar gembira dan keselamatan lahir batin, Nabi tidak menawarkan reward dalam bentuk materi, melainkan merangsang kecerdasan para murid, memperluas budi pekerti, serta mempertajam spiritual mereka. Demikian pula dalam hal hukuman, khususnya hukuman fisik, tidak populer dalam kamus pendidikan Islam.

Dalam diri manusia terdapat dua tenaga pendorong, yaitu kesenangan dan kesakitan. Secara umum manusia cenderung ingin mengulangi tingkah laku yang membawa pada kesenangan serta menghindari tingkah

${ }^{48}$ asy-Syarif, al Qur'an dan Terjemahnya, 624.

${ }^{49}$ Ruswan Thoyib, Pemikiran Pendidikan Islam Kajian Tokoh Klasik dan Kontemporer (Yogyakarta: Pustaka Pelajar, 1999), 141. 
laku atau perbuatan yang menimbulkan ketidaksenangan. ${ }^{50}$ Dengan diterapkannya penghargaan bagi orang yang berbuat baik, atau bisa dikatakan sesuai peraturan yang ada, diharapkan akan menjadi motivasi manusia untuk selalu berbuat sesuai aturan tersebut dan tidak melanggarnya.

Dalam Islam, penghargaan sering dikenal dengan istilah pahala.

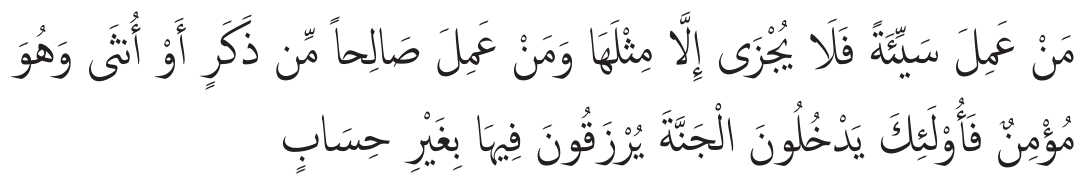

Dan barang siapa mengerjakan amal yang saleh baik laki-laki maupun perempuan sedang ia dalam keadaan beriman, maka mereka akan masuk surga, mereka diberi rezeki di dalamnya tanpa hisab. (QS. al-Mukmin [40]: 40) ${ }^{51}$

Ayat di atas menunjukkan bahwa siapapun orang beriman yang melakukan kebaikan akan memperoleh surga beserta seluruh fasilitasnya, balasan yang sangat diharapkan oleh semua manusia. Kemudian masalah pahala atau penghargaan ini diakui keberadaannya dalam rangka pembinaan kedisiplinan. Dengan demikian, para santri akan mendapatkan penghargaan khusus atas prestasi maupun ketaatannya dalam berdisiplin. Konsistensi berarti tingkat keseragaman atau stabilitas atau kecenderungan menuju kesamaan. Konsistensi harus menjadi ciri semua aspek disiplin, yaitu dalam peraturan, hukum maupun penghargaan..$^{52}$ Dalam menetapkan peraturan hendaknya berlaku secara umum bagi semua santri. Tidak ada pengecualian atau dispensasi bagi santri-santri tertentu. Penerapan hukuman atau penghargaan seharusnya juga berlaku sama, tidak ada yang dibeda-bedakan. Hal ini akan menumbuhkan perasaan yang sama bagi para santri, baik tanggung jawab atas perbuatan yang dilakukan maupun kesadaran terhadap konsekuensi mungkin yang akan diterima akibat perbuatan tersebut, serta menghilangkan kecemburuan sosial di antara mereka.

\footnotetext{
${ }^{50}$ Schaefer, Bagaimana Mendidik, 19.

${ }^{51}$ asy-Syarif, al Qur'an dan Terjemahnya, 765.

${ }^{52}$ Hurlock, Perkembangan Anak, 90
} 


\section{Penutup}

Pondok pesantren umumnya mempunyai aturan-aturan yang harus ditaati oleh para santri sehingga tujuan pendidikan di pesantren dapat terlaksana. Disiplin juga sangat diperlukan karena akan mendukung keberhasilan proses belajar mengajar. Upaya untuk mengembangkan disiplin diri bisa dilakukan dengan mengundang anak-anak untuk mengaktifkan diri dengan nilai-nilai moral untuk memiliki dan mengembangkan dasar-dasar disiplin diri. Dengan demikian, apabila disiplin diterapkan dengan baik, konsisten, dan konsekuen tentu akan berdampak positif bagi kehidupan dan perilaku peserta didik. Oleh karena itu, pesantren perlu mengupayakan situasi dan kondisi yang bisa membantu santri dalam mengembangkan disiplin diri. Kedisiplinan bukan merupakan sesuatu yang terjadi secara otomatis atau spontan pada diri seseorang, melainkan sikap tersebut terbentuk atas dasar beberapa faktor yang mempengaruhinya, misalnya 1) faktor pembawaan; 2) faktor kesadaran; 3) faktor minat; dan 4) faktor pengaruh pola pikir. Disiplin berkaitan dengan proses mengubah tingkah laku tersebut. Adapun beberapa hal yang perlu menjadi perhatian dalam rangka mengubah tingkah laku para santri adalah, pertama, peraturan adalah pola yang ditetapkan untuk tingkah laku. Tujuannya adalah untuk membekali anak dengan pedoman perilaku yang disetujui dalam situasi tertentu. ${ }^{53}$ Dengan adanya peraturan yang jelas, semua anggota kelompok akan melaksanakannya dengan baik. Di samping harus mentaati peraturan pondok pesantren, santri juga harus memahami dan mentaati pola-pola kebudayaan pondok pesantren yang berlaku. Adanya peraturan ini kemudian menjadi pijakan awal untuk memberikan penghargaan bagi yang memiliki prestasi atau hukuman bagi yang melanggarnya. Kedua, hukuman adalah suatu bentuk kerugian atau kesakitan yang ditimpakan kepada orang yang berbuat salah. Pelaksanaan hukuman dimaksudkan untuk menghalangi santri melakukan perbuatan salah yang pernah dilakukan, untuk mematuhi peraturan, memberi motivasi untuk menghindari perilaku yang tidak diterima di lingkungan pondok pesantren.

\footnotetext{
${ }^{53}$ Ibid., 85.
} 


\section{Daitar Pustaka}

Abrasyi, Muhammad Athiyah. Tarbiyah al-Islamiyyah wa Falsafatuha. Mesir: Isa al-Bani al-Halabi, 1975.

Ali, Lukman, et.al. Kamus Besar Bahasa Indonesia. Jakarta: Balai Pustaka, 1997.

Amin, Ahmad. Etika. Jakarta: Bulan Bintang, 1975.

Arief, Arma'i. Pengantar Ilmu dan Metodologi Pendidikan Islam. Jakarta: Ciputat Pers, 2002.

Arikunto, Suharsimi. Manajemen Pengajaran Secara Manusiawi. Jakarta: Rineka Cipta, 1993.

Budaiwi, A. Ali. Imbalan dan Hukuman Pengaruhnya bagi Pendidikan Anak. Jakarta: Gema Insani, 2002.

al-Bukhari. Shahih Bukhari. Juz I. Beirut: Dar al-Kutub al-Ilmiyah, 1992.

Darajat, Zakiah. Ilmu Jiwa Agama. Jakarta: Bulan Bintang, 1970.

Dhofier, Zamakhsyari. Tradisi Pesantren: Studi tentang Pandangan Hidup Kyai. Jakarta: LP3ES, 1990.

Dreikurs, Rudolf \& Pearl Cassel. Disiplin Tanpa Hukuman. Bandung: Remaja Karya, 1986.

Durkheim, Emile. Pendidikan Moral: Suatu Studi Teori dan Aplikasi Sosiologi Pendidikan. Jakarta: Erlangga, 1990.

Ellison, Sheila \& Barbara Ann Barnett. 35 Ways to Help Your Children Grow. Illinois: Sourcebooks Inc, 1996.

Fahmi, Asma Hasan. Sejarah Filsafat Pendidikan Islam. Jakarta: Bulan Bintang, 1979.

Gunarso, Singgih D. Psikologi untuk Membimbing. Jakarta: PT. BPK Gunung Mulia, 2000.

Hamalik, Oemar. Psikologi Belajar dan Mengajar. Bandung: Penerbit 
Sinar Baru Algesindo, 2002.

Hamid, Muhammad Muhyiddin Abdul. Sunan Abu Daud. Juz I. Indonesia: Maktabah Dahlan, tt.

Haq, Abu Thayyib Muhammad Syamsul. Aunul Ma'bud: Syarah Sunan Abu Daud. Juz II. Beirut: Daar al-Fikr, tt.

Hendro, Sehedi. Gerakan Disiplin Nasional (GDN) Menyongsong Era Keterbukaan Tahun 2020. Jakarta: CV. Navindo Pustaka Mandiri, 1996.

Hernowo. Quantum Reading: Cara Cepat nan Bermanfaat untuk MerangSang Potensi Membaca. Bandung: Penerbit MLC, 2003.

Homby, AS. Oxford Advanced Learner's Dictionary. Oxford: Oxford University Press, 1995.

Hurlock, Elizabeth B. Perkembangan Anak, terj. Med Meitasari Tjandrasa. Jakarta: Erlangga, 1999.

Husain, Abdurrazak. Dinul Islam. Bandung: al-Ma’arif, 1989.

Junaedi, Mahfud. Ilmu Pendidikan Islam Filsafat dan Pengembangan. Semarang: Rasail Media Group, 2010.

Kartono, Kartini. Pengantar Mendidik Ilmu Teoritis: Apakah Pendidikan Masih Diperlukan. Bandung: Mandar Maju, 1992.

Kasiram, Moh. Ilmu Jiwa Perkembangan. Surabaya: Usaha Nasional, 1983.

Khadim Mujamma' al Haramain asy Syarifain al Malik Fahd li thiba'at al Mushhaf asy-Syarif, al Qur'an dan Terjemahnya. tt: tt.tt.

Lincoln, Yvonna S \& Ego G. Guba. Naturalistic Inquiry. California: Sage Pub, 1985.

Mas'ud, Abdurrahman, "Reward and Punishment dalam Pendidikan Islam," Jurnal Media. Edisi 28, Th. IV (November 1999).

Muhadjir, Noeng. Metodologi Penelitian Kualitatif. Yogyakarta: Rake Sarasin, 1996. 
Mujib, Muhammad Abdul, et.al. Kamus Istilah Fiqih. Jakarta: Pustaka Firdaus, 1994.

Mursal, Taher et.al. Kamus Ilmu Jiwa dan Pendidikan. Bandung: alMaarif, 1997.

Muthohar, Ahmad. Respons Stakeholder terhadap Model Fit and Proper Test bagi Kepala Madrasah: Studi Kasus Madrasah Aliyah di Kota Semarang. Semarang: IAIN Walisongo, 2005.

Nasution, S. Didaktik Asas-Asas Mengajar. Bandung: Jemmars, 1982. . Sosiologi Pendidikan. Bandung: Bumi Aksara, 1995. . Metode Penelitian Naturalistik Kualitatif. Bandung: Tarsito, 1988.

Nata, H. Abudin. Filsafat Pendidikan Islam. Jakarta: Logos, 2001.

Outhman, Ahmad Ismail. Dinamika Pesantren dan Madrasah: Dari Mengaji ke Mengkaji. Semarang: IAIN Walisongo dengan Pustaka Pelajar Yogyakarta, 2002.

Prijodarminto, Soegeng. Disiplin Kiat Menuju Sukses. Jakarta: Pradnya Paramita, 1987.

Qomar, Mujamil. Pesantren: Dari Transformasi Metodologi Menuju Demokratisasi Institusi. Jakarta: Penerbit Erlangga, 1996.

Qutb, Muhammad. Sistem Pendidikan Islam. Bandung: PT. al-Ma'arif, 1993.

Quthb, Muhammad Ali. Auladuna fi Dlau'i at-Tarbiyah al-Islamiyah: Sang Anak dalam Naungan Pendidikan Islam. Kairo: Maktabah Qur'an, 1993.

Sastropoetra, RA. Santoso. Partisipasi, Komunikasi, Persuasi, dan Disiplin dalam Pembangunan Nasional. Bandung: Penerbit Alumni, 1988.

Rahmat, Jalaludin. Metode Penelitian Komunikasi. Bandung, PT. Rosdakarya, 2000.

Saridjo, Marwan. Sejarah Pondok Pesantren di Indonesia. Jakarta: Dharma Bhakti, 1982. 
Schaefer, Charles. Bagaimana Membimbing, Mendidik, dan Mendisiplinkan Anak Secara Efektif, terj. Turman Sirait. Jakarta: Restu Agung, 1979 (2000).

al-Sijistani, Abu Daud Sulaiman Ibn al-Asy'ats. Sunan Abu Daud, Jilid I. Beirut, Daar al-Fikr, tt.

Simandjuntak, B. Latar Belakang Kenakalan Remaja. Bandung: Alumni, 1984.

Siti, Meichati. Pendidikan Sistematis. Yogyakarta: FIP IKIP Yogyakarta.

Spock, Benyamin. Raising Children in a Difficult Time, terj. Wunan Jaya K. Liotohe. Jakarta: Gunung Jati, 1982.

Sujiono, Bambang, et.al. Mencerdaskan Perilaku Anak Usia Dini. Jakarta: PT. Elex Media Komputindo, 2005.

Sukardi, Dewa Ketut. Bimbingan Karir di Sekolah-Sekolah. Jakarta: CV. Ghalia Indonesia, 1994.

Thoha, H.M. Chabib. Kapita Selekta Pendidikan Islam. Yogyakarta: Pustaka Pelajar, 1996.

Thoyib, Ruswan et.al. Pemikiran Pendidikan Islam: Kajian Tokoh Klasik dan Kontemporer. Yogyakarta: Pustaka Pelajar, 1999.

Tu'u, Tulus. Peran Disiplin pada Perilaku dan Prestasi Siswa. Jakarta: Grasindo, 2004.

Ulwan, Abdullah Nasih. Pendidikan Anak dalam Islam. Jilid II. Jakarta: Pustaka Amani, 1999.

Wahid, Abdurrahman. Menggerakkan Tradisi: Esai-esai Pesantren. Yogyakarta: LKiS, 2007.

White, Ellen G. Mendidik dan Membimbing Anak. Bandung: Indonesia Publishing House, 1998.

Widagdho, Djoko, et.al. Ilmu Budaya Dasar. Jakarta: Bumi Aksara, 1994.

Yunus, Mahmud \& Muhammad Qasim Bakri. At-Tarbiyah wa al-Ta'lim. Juz II. Ponorogo: Darussalam Press, 1991. 
Zanikhan. "Pengertian dan Unsur Jarimah Takzir." http://zanikhan.multiply.com/ journal/item/694.

Zarnuji. Ta'lim al Muta’allim. Semarang: Toha Putra, tt. 